\title{
What Was So New about the New Story? Modernist Realism in the Hindi Nayī Kahānī
}

\begin{abstract}
T N RAJENDRA YADAV'S SHORT STORY “Śarat aura Premacanda” ("Sharat and Premchand"), written in Hindi and published in 1954, an unnamed narrator climbs into a cycle rickshaw, after sending off a woman acquaintance at the local train station in a small North Indian city. Distraught, he orders the driver to cycle him to the city center a few miles away. As the driver toils to maneuver the cycle over bumpy terrain, the narrator ruminates in the back seat, roving between reflections about the woman and his own emotional state. Intermittently, the journey jars the narrator back into his present surroundings, leading him to weave observations about the setting into his stream of thought:

Ahead in the east the gigantic petals of an enormous red rose began to smile in the dewy darkness. The rickshaw driver's coat began to sway this way and that in front of my eyes. The air was chilly, it seemed he should button his vest, didn't he want to? Just as he rocked side to side in the driver's seat, so too did my mind, spreading out (Yadav, "Śarat" 11). ${ }^{1}$
\end{abstract}

In early moments of the story like this one, the driver's motions and the surrounding landscape magnify the narrator's state of internal upheaval, and so the world around him is meaningful only insofar as it resonates with his own despair. Over the course of his ride, the narrator moves into the present tense, drifting in and out of consciousness, the rickshaw's movements signposting his own mental condition. In his most lucidly reflective moments, he compares his situation to various wellknown literary scenes featuring viraha - the poetic trope of longing or distress caused by separation from one's lover. Such exaggerated, borderline mawkish musings dominate the majority of his journey.

But in the final instance, "Śarat aura Premacanda" takes a turn. As he bitterly curses the woman he sent off-his childhood sweetheart, now the wife of another

I am grateful to a number of people for their generous and thoughtful feedback: Jessica Birkenholtz, Vasudha Dalmia, Asher Ghertner, Chie Ikeya, Emrah Efe Khayyat, Mukti Mangharam, Farina Mir, Kannan Muthukrishnan, Anjali Nerlekar, Francesca Orsini, and S. Shankar, as well as audiences at the University of California, Berkeley, and the Nehru Memorial Library and Museum in Delhi.

${ }^{1}$ All translations in this essay are mine. 
man - the narrator begins to observe his surroundings more keenly. He leans his head against the back of the driver's seat and tearfully watches the road passing beneath him:

My teardrops begin to fall on the road again.... But suddenly I'm surprised. I must have left a stream of tears beneath me, but there's another line of droplets exactly the same running ahead, too. Who else is crying? It occurs to me. I'm utterly taken aback. The climb is quite steep.... The rickshaw driver has dismounted and is pulling the rickshaw holding the handle with one hand and the seat with the other. The veins protruding from his distended calves throb with every step. I realize that even in such winter conditions, the sweat pouring from his forehead, temples, and back is beading up and dripping down.... How lifeless are my tears that evaporate as they hit the earth-each drop of his is searing like acid, and I turn back to look-it seems as if the two drops have merged together behind me-one having fallen and about to dry out and one stubbornly remaining upon the face of a rock in the distance — sizzling. (18-19)

The story ends with this attempt to bring together two very different, yet wholly believable, or "realistic," experiences-one emotional and the other, physicalthrough a hyphenated compression of images. The rickshaw driver's backbreaking labor confronts the narrator in the midst of his weepy monologue, awakening him to the insularity of his perspective and lack of attention to the basic conditions of human existence. Yadav's underlying objective in this story, it might be interpreted, is to show how realist literary materialism ultimately trumps the egotistical impulses of modernist individualism.

\section{Metaliterary Discourses}

Nevertheless, in this essay I offer a different reading of "Śarat aura Premacanda," demonstrating how the story articulates an entirely new modernist realist modeand not just a pithy critique of middle-class self-absorption - that arose with the 1950s and 1960s Naȳ̄ Kahānī (New Story) Movement. Yadav's story is exemplary of the movement, a preeminent corpus within the Hindi canon known for its innovative use of the short story to express themes of alienation, disconnection, and disillusionment following Indian Independence (1947). Responding to unprecedented social change in the postindependence milieu-communal hostility in the aftermath of Partition; political contestation over economic policy and national language; increased migration to Indian metropolises for education and employment; and the emergence of new, individual-rights oriented perspectives regarding class, caste, gender, and religion — nayī kahānī writers posed themes of unbelonging as means for exploring how individuals might move away from the outdated colonial past into a more modern postcolonial present.

Upon first reading, Yadav's story might appear contrived, the concluding image blatantly advancing a social realist agenda. Existing scholarship has advanced this and other similarly dichotomous readings primarily because it has considered the movement's theoretical concepts and literary historical positioning as backdrop to, rather than constitutive of, form and meaning. Viewing nayì kahānī fiction as either realist (e.g., Roadarmel) or modernist (e.g., Kumar) — or sometimes both at once (e.g., de Bruijn, "Nirmal Verma") — scholars have overlooked the novel modernist realist mode that the movement sought to construct. ${ }^{2}$ However, as much as nayì

${ }^{2}$ Hindi-language scholarship on the Naȳ̄ Kahānī Movement is too voluminous to list here, but key overviews include Ashk; Madhuresh; G. Rai; D. Singh. English-language scholarship on the movement 
kahānī stories themselves, what made the movement so influential was the ample body of criticism and literary history that its writers produced. Incorporating a view toward this larger "metaliterary" corpus in relation to which properly "literary" nayī kahānī texts were produced, this essay illustrates how the movement's stories were exercises in criticism as much as fiction.

The case of the nayī kahānī highlights, I therefore argue, the necessity of attending to the critical texts, literary historical debates, and institutions surrounding practices of fiction to decipher how realist and modernist formations intersect and shape each other, coalescing to form unique, historically and geographically situated aesthetic modes. Despite its efforts to reach beyond Eurocentric models of center and periphery, a growing body of literature on realisms and modernismsincluding work on "geomodernisms," "modernism in the world," "postcolonial modernism," "peripheral modernisms," and "peripheral realisms" — has paid minimal attention to the ways that canonization processes actively shape how realist and modernist formations construct notions of literariness. ${ }^{3}$ I am not referring, here, to literary history "ordinarily conceived" - that is, studies of national literatures, histories of individual authors, or interpretations of texts over time (Casanova 142). Rather, in arguing for a literary historical approach, I am pointing to the need for understanding texts vis-à-vis not only their historical contexts — as, for example, Said would have it-but also their literary historical contexts. How writers conceive of literary history and position themselves within its trajectories matters for how they define literature and express literary value in their texts. Attending to the metaliterary alongside the literary need not reproduce the canonizing effects that texts and literary fields create. On the contrary, heeding the relationship of the literary to the metaliterary enables us to make such boundary-fixing processes and their ensuing exclusions clear.

This essay demonstrates how the nayī kahānī writers' multipronged literary and metaliterary production enabled them to chart a new direction in the Hindi canon by using the short story to redefine the literary realism prevalent in the late colonial era. They inaugurated what might be called a Hindi modernist realism-or yathārth, in nayī kahānī terms - characterized by heightened attention to the formal conventions of genre, rhetoric, and style on one hand, and deep writerly commitment to social reality on the other. Critiquing the didacticism of idealistic realism and other strains of progressivism, the provincialism of literary regionalism, and the sentimental individualism of new poetry and experimental modernism more broadly, naȳ̄ kahānī writers situated themselves at a literary historical-and not just historical - crossroads and formulated modernist realism as a synthesis of existing currents of Hindi literary thought.

Modernist realism operated in this context as a mode of enunciation that oriented nayī kahānī texts toward readers. It therefore differed from but articulated

includes Ansari, "Changes"; Ansari, "Indian Social Reality"; Damsteegt, "Ajneya”; Damsteegt, "Early Short Stories"; Damsteegt, "Mohan Rakes"; de Bruijn, "Impostors"; de Bruijn, "Nirmal Varma"; de Bruijn, "Under Indian Eyes”; Kumar; Prakash; Roadarmel; Svobodová. See, also, Orsini, "Konrad Meisig."

${ }^{3}$ I am thinking of scholarship such as Doyle and Winkiel; Friedman, "Definitional Excursions"; Friedman, "Periodizing Modernism"; Friedman, "Planetarity"; Gikandi, "Preface"; Lazarus; Parry; WReC. 
with the formal and thematic characteristics of the short-story genre. ${ }^{4}$ Combining rhetorical strategies - such as the use of a shifting narrative voice, allegorical descriptions of landscape, and implicit references to existing Hindi literary debates - with structural and thematic tensions between form and content, the nayī kahānī sought to situate readers as possible characters as well as authors. This new author/character/reader dynamic constituted modernist realist yathārth (reality) and enabled the movement to introduce into the Hindi sphere a radically different worldview that was shaped by secularism and alienation. Through these philosophical outlooks, it sought to transform the middle class into a universally inclusive category in postcolonial India. Addressing an already-existing, middleclass readership that was well aware of the Hindi literary field, nayī kahānī writing contradictorily concealed the inequalities of class, caste, religion, and gender that led to individuals' sense of unbelonging in postcolonial North India. Yet it also produced an enduring politics of representation, which stipulated that "true" representation stems from lived experience.

I begin by situating modernist realism within current discussions of peripheral realisms, arguing this naȳ kahānī mode proposed a universally inclusive vision of the middle class in response to cultural and political transitions spurred by decolonization. I then describe how the Nayī Kahānī Movement emerged amid heated literary debates about realism, modernism, and the purpose of literature. In the final sections, I return to "Śarat aura Premacanda" and other exemplary naȳ kahānī stories to demonstrate how modernist realism established a transposability between the positions of author, character, and reader, thereby locating "authentic" representation in the writer's personal experience. Exploring how the Nayī Kahānī Movement produced abiding claims about literariness, this essay offers the Hindi short story as inroads for reconsidering scholarly approaches to realism, modernism, and postcolonial and world literature.

\section{A Hidden Third Term}

Nayī kahānī modernist realism, like realisms and modernisms everywhere, is concerned with literature's relationship to "truth" —-some unnameable, universal, and fundamentally humanistic essence communicable through literature-as opposed to reality in and of itself. It proposes an intricate, reflexive, indirect affiliation with

\footnotetext{
4 I view genre as a teleological formation comprising community-based expectations and norms that externally surround and internally structure a text, and mode as the rhetorical techniques through which texts position authors and characters in relation to readers-whether through the direct speech of the author, the represented speech of the characters, or some mixture of the two. In the wake of German Romantic thinkers' efforts to create a broader philosophy of genre, mode has come to designate a thematic quality equated with generic "natural form," "inner form," "style," "attitude," "tone," or "mode," all of which suggest some primary quality in herent to a given genre, distinguishing it from all others. See, for example, Bakhtin, Dialogic 3-83; Bakhtin, "Problem"; Frye 33-51; Genette, Architext; Genette, Narrative Discourse; Jameson, Political Unconscious 89-136; Lukács, Theory 11-69; Todorov, 13-26; Wellek and Warren 235-44. However, I find it useful to differentiate the effects of genres (such as the short story or novel) from those of modes (such as realism or modernism) to track the particular equalizing relationship between authors, characters, and readers that the Naȳi Kahānī Movement sought to establish. Elsewhere, I take up the question of genre - that is, of why nayī kahānī writers focused almost exclusively on the short story, rather than the novel or poetry, to carry out their literary project (Mani, Idea). Here, I focus on mode to understand how the movement constructed a modernist realism that could then be transplanted across genres, such as the novel and poetry.
} 
external reality, rather than superficial mimetic likeness. Naȳi kahānī modernist realism exists, together with realisms and modernisms of all varieties, along a discursive continuum concerned with the nature and representability of reality and individuals' relationship to it. ${ }^{5}$

Still, I want to suggest that this Hindi literary mode operates differently than current models of realism, modernism, and modernist realism. Take for example, the Warrick Research Collective's (WReC) recent discussion of modernist realism, which seeks to revise the privileging of modernism over realism and its decidedly European orientation. Building on Fredric Jameson's perfunctory speculation that "a modernist realism would begin to emerge when the traditional methods of narrative representation (novelistic realism) are used and then undermined" (Jameson, "Antinomies" 475), the WReC argues that "one of the paradigmatic sites of emergence of a 'modernist realism' ... is the world of the semi-periphery, in which 'local' and 'global' forces come together in conflictual and unsteady flux" (67). Modernist realism falls under the rubric of what the WReC calls peripheral realism - a set of narrative strategies that register the combined and uneven development of the world-system. "Our assumption," writes the WReC, "is ... that the effectivity of the world system will necessarily be discernable in any modern literary work" (20) through formal features such as "anti-linear plots, metanarratorial devices, un-rounded characters, unreliable narrators, contradictory points of view... discernable wherever literary works are composed that mediate the lived experience of capitalism's bewildering creative destruction (or destructive creation)" (51). ${ }^{6}$ Modernist realism, as the WReC conceives of it, appears to be no less than modernism, interpreted through the triangulated lens of capitalist transformation, imperial violence, and postcolonial discontent.

While naȳi kahānī modernist realism, like the WReC's peripheral realism, emerged in "the harsh glare of past and present imperial and colonial dispensations" (52), I believe that this mode urges a reconsideration of a key assumption with which the WReC begins - that peripheral realism is rooted in definitive, already prescribed narrative strategies that "undermine traditional methods of narrative representation." The WReC's starting point is a clearly delimited core-periphery worldsystem within which peripheral realism proliferates - interrogating, transforming, or overturning the claims of traditional realism. For this reason, the peripheral realism that the WReC theorizes can only offer a picture of reality that is discordant or fantastical in comparison to realism's conventional forms. It is possible, however, for peripheral realisms to be considered in less totalizing terms, such as those proposed by Jed Esty and Colleen Lye, which "approach the world-system as partially, potentially describable ... [and] invite their publics to grasp the world-system, via its local appearances or epiphenomenal effects, and not to imagine it as a foreclosed or fully

5 Thinkers, European and South Asian among others, have theorized the path from literature to reality as tortuous, duplicitous even. For discussion of classical Western realism, see, for example, Adorno et al.; Auerbach, "Figura"; Auerbach, Mimesis; Barthes, "Reality Effect"; Jakobson, "On Realism"; Jameson, Antinomies; Lukács, Meaning; Lukács, "To Narrate." For more on realism in South Asia, see Anjaria; Kapur; Mukherjee; Sangari; Tharu.

6 The WReC acknowledges that these features could also be addressed under the name of modernism-and, indeed, a large part of their chapter on "irrealism" is drawn from WReC member Benita Parry's earlier work on peripheral modernisms (WReC 81-95). However, they also insist that "to read modernist literature in the light of combined and uneven development is to read it with one eye toward its realism" (67), which references the "real" of globally disperse systemic crises of modernity. 
narrativized entity" (285). For Esty and Lye, peripheral realisms are shaped by the presence of other, unexpected forms which have been incorporated into the realism-modernism continuum to address location-specific conundrums-for example, romance in colonial African literature (Gikandi, "Realism"), metonymy in postcolonial North Indian Dalit fiction (Gajarawala, "Casteized Consciousness"), or derangement in Naipaul's biographical reflections of Trinidad (Krishnan). These are forms elided by the peripheral realist set of narratives strategies that the WReC describes. The case of the nayī kahānī proffers an additional third term, literary history, which has been integral to structuring the realism/modernism debate. Literary history remains hidden from the view of theoretical standpoints that valorize only those critiques of capitalist and imperialist exploitation made evident by antagonistic aesthetic strategies and forms.

In naȳ kahānī modernist realism, constant interchange between literary and metaliterary texts stood in place of explicit references to the colonial past. Such references were vehemently disallowed by the promises of freedom and equality that Indian Independence heralded - promises which blanketed early postcolonial cultural and political enterprises with an aura of hopeful cooperation and solidarity. The nayī kahānī modernist realist mode was therefore marked by a utopian impulse and ideological imperative to imagine a landscape free from the scars of colonialism and the violence of decolonization: the atrocities and displacement of Partition; frenzied debates about national language; brutal struggles over land and resources; and intense protest surrounding caste, religious, and regional identities. Replacing history with literary history allowed the nayī kahānī to articulate dissatisfaction, discontent, and estrangement-sensibilities which were incongruent with the postcolonial state's project to install "unity in diversity."

For naȳi kahānī writers, literary history served as a kind of epistemological basis around which to cohere community and through which to invite readers to place themselves in the positions of middle-class authors and characters. They thereby sought to construct a commonsense understanding of "people like us" - a notion deeply engaged, though by no means synonymous, with the secular, middle-class politics of the Nehruvian era more broadly. ${ }^{7}$ The movement was driven by the imagination of a modern Indian habitus that was Hindi-based yet cosmopolitan in scope, secular yet informed by tradition, and commonplace yet rich in intertextuality. (See, for example, Kamleshwar, Naȳ Kahān̄̄ 99; Rakesh, Sāinskṛtik 24-25; N. Singh, Kahān̄ 99; Yadav, Premacanda 12-13.) In this worldview, "loneliness [akelāpan], helplessness [asahayat $\bar{a}$ ], and worthlessness [vyarthat $\bar{a}]$ " became representative of general human experience (Yadav, Premacanda 12). Mobilizing an aesthetic inspired by existentialism (astivavā $d$ ) — which nayī kahānī writers viewed as embodying the very "question of independence" (N. Singh, Kahān̄ 176) — the Nayī Kahānī

\footnotetext{
${ }^{7}$ Nehru's postindependence policies favored the already existing middle-class minority that had risen to power through colonial educational and bureaucratic channels-in Nehru's case, an affluent, rationally inclined, upper-caste Hindu, English-speaking minority that comprised no more than 5 to 10 percent of the population. The administration actively imagined this class as a proxy representing the interests of the nation. See Deshpande, Contemporary India 142-48; Fernandes 1-28; Kaviraj. For a general definition of the term middle class and its meanings in popular usage in India, see Deshpande, "Mapping." Hardly living the moneyed lifestyles of the bureaucratic elite, nayī kahānī writers offered an alternative perspective on the middle class.
} 
Movement projected middle-class identity as an intellectual community to which everyone could belong. " "That middle class [ madhyavarg] of which we were all a part...we [understood it as] avant-garde [agragāmi].... We believed it would give us direction, and we assumed that all the world's philosophies and doctrines [vicārdhārā], everything, came from the middle class" ("Sunie"), reflected Yadav in a 2010 interview.

Actualizing the middle class as a universally inclusive category required, however, that nayī kahānī fiction obscure embodied experiences of class, caste, religion, and gender. It had to subordinate the sources of alienation to the aestheticization of alienation in and of itself. This meant speaking in oblique terms about Partition and the injustices of class, caste, and gender - generalizing the unique circumstances of refugees, women, and laborers as symbolic of those experienced by all Indian citizens. "Śarat aura Premacanda" provides a quintessential example: the rickshaw driver's grueling labor becomes a means for the narrator's personal realizations and Yadav's critique of individualistic modernism, while its class- and castespecific nature goes unmentioned. The class and caste dimensions that shape the rickshaw driver's experiences are, in fact, unimaginable from the narrator's point of view beyond his meager allusions to them. Similarly, the other stories that I examine below abstract the female characters' gendered experiences of discrimination to create an atmosphere seductively heavy with disconnection and hopelessness. The nayī kahānī vision of the middle class conceived of readers and created protagonists whose backgrounds were, more or less, like those of nayī kahānī writers themselves - readers and protagonists who were exceptionally aware of the field of Hindi fiction. Through the deliberate literary historical positioning of their fiction, rigorous theorization of its formal, thematic, and rhetorical features, and extensive production of exemplary stories, naȳ kahānī writers grounded literary production in the emotional, intellectual, and social experiences that the middle-class Hindi writer personally endured. Literary history seeded a narrative of what Neil Lazarus has characterized as postcolonial disconsolation, shaped-in the case of the nayi kahānī-by the absenting of communal, religious, and colonial history (21-88).

\section{The Naȳ̄ Kahān̄̄in in Literary History}

By the mid-1950s, Hindi writers had created significant momentum around a new approach to short-story writing through coffee-house style gatherings and larger scale conferences taking place in Allahabad, Calcutta, and Delhi, as well as, most effectively, through short stories, critical essays, reviews, and letters to the

\footnotetext{
8 Also see Kamleshwar 174-89. Naȳ̄ kahānī writers drew extensively on Kierkegaard, Sartre, and Camus to illustrate how their movement was part of a global effort to make sense of the human condition following the Holocaust, World War II, and ongoing processes of decolonization.

${ }^{9}$ A handful of short stories and novels about Partition came out in the two decades immediately following Independence, a few written by nayī kahānī writers, but the majority penned by writers connected with the Progressive Writers' Movement. See, for example, Ahmed 162-63; Jalil 306-7. The body of Partition literature in Hindi and Urdu grew significantly after 1970. During the 1950s and 1960s, both nayī kahānī and Urdu naya a afsānā (new story) writers explored similar themes of alienation through a secular humanist lens, while simultaneously absenting the event of Partition itself. As Aijaz Ahmad argues, "for almost a whole generation [after Partition], the [literary] community tried to remain one while the nation-states became two" (111-12).
} 
editor that they published in literary magazines of the time. Almost all major Hindi magazines featured articles and columns on the naȳ kahānī from the mid-1950s through the 1960s. ${ }^{10}$ The movement comprised, by and large, a new generation of Hindi writers who were born in the late 1920s and early 1930s - too young to have participated in the Independence movement to any sustained extent. Kamleshwar (1932-2007), Mohan Rakesh (1925-72), and Rajendra Yadav (1929-2013) were considered the primary thinkers at the forefront of the movement, and Yadav's wife Mannu Bhandari (b. 1931) was a central interlocutor in nayī kahānī discussions, many of which took place at Yadav's own publishing house. ${ }^{11}$ Nayī kahānī writers generally came from upper-caste Hindu families, were university educated, lived in smaller cities across North India, and faced a new nation rife with possibility, yet upended by the devastation of Partition. They were youthful, creative intellectuals who saw themselves as uniquely poised to break from past traditions and interrogate the postindependence condition anew. In their view, older-generation writers held omniscient control over characters, clinging to an old-fashioned understanding of reality even though conditions had changed. ${ }^{12}$ Postindependence short-story writers maintained that no single morality could be held as fixed or superior during the transitional postindependence moment, particularly because it was ideological rigidity and religious orthodoxy that had led to Partition violence and communal divisiveness in their view (see, for example, Kamleshwar, Naȳ Kahānī 96).

Yet, however differently they viewed their work from that which came before them, nayī kahānī writers also recognized and rigorously documented their debt to their short story predecessors, and they viewed such documentation as central to the movement itself. Yadav's nayī kahānī tracts, in particular, provided long

10 The primary magazines that published naȳ kahānī fiction and essays were Dharmayuga, Jñānodaya,

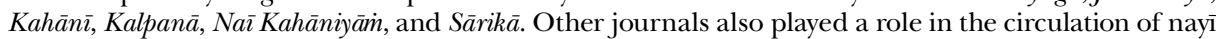
kahānī stories and debates, such as Hams, Lahr, Māyā, Nikarș, Pratīk, and Sañket. Apart from regular articles and reviews on contemporary short stories and the short story form in these magazines, columns definitive of naȳ̄ kahānī debates and philosophies include "Āj kī Hindī Kahān̄̄" ("The Hindi Short Story Today"), published in Kahān̄ and authored by a different writer each month; Mohan Rakesh's "Bakalam Khud" ("A Pen and I") and Namvar Singh's "Hāśiye Par" ("From the Margins") columns, both published in Naī Kahāniyām; and the 1964 year-long series of autobiographical reflections by nayi kahānī writers titled "Ek Kathā Daśak" ("A Decade of the Story"), published in Dharmayuga.

11 See Bhandari, Ek Kahānī; Rakesh, Mohan Rākeś; Yadav, Mud-Mudke. Tyagi discusses the contemporary perception of Kamleshwar, Rakesh, and Yadav as front-runners of the movement. For a list of writers and critics generally associated with the movement, see Madhuresh; Roadarmel; D. Singh. Those now identified with the movement were, in practice, sometimes at odds with its philosophies, or marginally, if at all, involved. For example, Nirmal Verma's (1925-2005) stories have been hailed as paragons of the nayi kahānī (e.g., N. Singh, Kahān̄ 52-65), although Kamleshwar, Rakesh, and Yadav, as well as Verma himself, considered him an outsider to the movement (e.g., de Bruijn, "Nirmal Varma"; Rakesh, "Bakalam Khud”; cf., Verma, Hara Bāriš; Verma, "Nayī Kahānı̄”). Namvar Singh (1927-2019), whose essays on the naȳ kahānī were formative in developing the conceptual language of the movement, saw his role as that of an antagonist (N. Singh, Kahān̄̄ n.p.). Naȳ̄ Kahān̄i: Sandarbh Aura Prakṛt̄̄, edited by Hindi critic Devishankar Awasthi (1930-1966), provides a compendium of differing perspectives on the movement, which were written during the period that it took shape.

12 The older generation to which naȳ kahānī writers referred-exemplified by the psychological ( manovaijñanik) tradition of Jainendra Kumar (1905-88), the progressivist (pragativājē) tradition of Yashpal (1903-76), and the experimentalist ( prayogvādī) tradition of Sachchidananda Hirananda Vatsyayan "Agyeya" (1911-87) — was still active in the 1950s and 1960s. Naȳ kahānī writers characterized the writers of this generation as "against the times" (samay ke prati) because of the seemingly overt and rigid, albeit varied, ideological stances they put forth in their writing (Kamleshwar, Nayi Kahāni 95-102; see also Rakesh, Sä̀mskṛtik 30-45; Yadav, "Ek Duniyā”). 
lists that categorized writers' contributions and specific pioneering stories (see "Ek Duniyā"; "Kahānī"; Kahān̄i). In them, he closely reproduced the existing, largely Hinduized historiography of the Hindi short story from its roots in the Vedas, to its early development in the Puranas and epics, to its stagnation in the medieval era, and finally, to its reinvigoration in colonial India. Affirming this historical mapping enabled Yadav to situate the nayī kahānī within a literary tradition already recognizable to the middle-class, Hindi-speaking, Hindu community of readers that his predecessors had established, while also reassessing and reconfiguring that tradition in light of the postindependence present (cf., Premchand, Kuch Vicār). In addition, Yadav clearly identified the modern Hindi forebears to the naȳ kahānī, providing detailed overviews of each writer's major stories and the ways in which each contributed to the development of the story form. When Yadav observed in 1978, almost a decade after the movement had dissipated, that "the nayī kahānī was the first, and perhaps in any real sense, the last movement [ändolan] up till now in the entire journey of the Hindi story" (Premacanda 93), he confirmed the overwhelming success of his endeavors to establish the nayī kahānī as part of the Hindi canon. Such moves elevated the short story above other genres within the postindependence Hindi literary field and helped to assemble nayī kahānī writing into a movement.

Nayī Kahānī writers also conscientiously situated their project in relation to naȳ kavitā (new poetry) and äncalik (regional) writing, the two literary trends contemporaneous with the Nayī Kahānī Movement. This enabled them to distinguish from other genres the newness and uniqueness of the short story for examining the postindependence context. The term nayi kavitā, or new poetry, arose in the 1940s with Agyeya's theorization of prayogvād, or experimentalism (see Agyeya, Dūsra Saptak; Tār Saptak). Agyeya discussed naȳ̄ kavitā as a type of prayogvādī (experimentalist) writing that shifted away from Hindi literary concerns about social relevance and toward the search for poetic essence, the integrity of the individual, and experimentation with language and form (see Lotz; Rosenstein; N. Singh, Kavita $)$. By defining the nayī kahānī in relation to nayī kavitā, Namvar Singh underscored the significance of the nayī kahānī. He brought the term into common parlance and marked a shift in generic focus, arguing that "from the perspective of literary forms, the short story alone is extremely modern" (Kahānī 13). According to nayī kahānī writers, not only was poetry - even "new poetry" — an older genre that lacked the same access to modernity as the short story, but also its focus was too individualistic, its theoretical framework too mired in tradition, and its perspective too detached from everyday readers. Conversely, the short story was linked to modern day-today sociality wherein the writer took cognizance of the individual's responsibility toward others: "Experience along with its circumstances, expression along with the reader - the art of the short story... is for understanding and consoling [ sambodhan] others, not the self" (Yadav, "Ek Duniyā" 48).

Nayī kahānī treatises took a slightly different approach in framing their relationship to äncalikt $\bar{a}$ (regional writing), the other main literary trend the time. Áncal (meaning "border") came to signify the margins-geographically, linguistically, and culturally - in Hindi literature. Writers who subscribed to āncaliktā focused on the rural regions of the nation, rather than its urban centers, depicting the lives of 
peasants, fisher people, and tribals in their local dialects and through their local customs and traditions. Nayī kahānī writers viewed āncaliktā as a trend that fell within the scope of the nayī kahānī and emphasized that the distinction between urban and rural was a misguided one (see, for example, Rakesh, "Bakalam Khud" 77). According to Yadav and others, the forces affecting change in postindependence India were inherently urban, and this was what the nayī kahānī struggled to depict and make sense of (Yadav, "Ek Duniyā" 40-41; see also Rakesh, Sāmskṛtik 34; N. Singh, Kahānī 29). Although nayī kahānī writers often set their stories in remote mountain, seaside, or village landscapes, they focused almost exclusively on urban sensibilities-secular, nuclear, middle-class domesticity; modern companionate romance; unrealizable individual desire; intellectual and emotional turmoil; and the transient lifestyles resulting from unstable white-collar working conditions.

In distinguishing themselves from āncalik writers, urban-focused nayī kahānī writers consciously examined struggles that they viewed as specific to the newly emerging postindependence middle class. Individuals of this class came from savarna (caste Hindu) joint families that were now dispersing due to economic pressures and changing norms surrounding religious custom and kinship relations. They distanced themselves from the ritualism and sectarianism associated with their parents' generation and came to larger cities seeking new forms of employment in a society deeply impacted by growing industrialization and urbanization. It was this search for a white-collar, nuclear, urban way of life, alongside a decisive break from older forms of communal sociality, that urban-focused nayī kahānī writers aestheticized. In doing so, they countered the anncalik critique that urbanity was not the prevalent experience of postindependence Indian life (see, for example, Rakesh, Sāmskrtik 35). Uncertainty, disillusionment, self-doubt, skepticism, alienation, fragmentation, transitoriness - these were the compelling narrative tendencies that marked the quotidian lives of nayī kahānī characters.

\section{The Modernist Realist Equation}

[The naȳ kahānī writer] had to grasp his truth through his own environment and feelings. This change in perspective [from the previous generation] began to alter the short story on several levels [dharätal]. Now the language of the story did not remain so singular. Such images [bimb], symbols [pratīk], and meanings [arth] began to arise in [the form] that portrayed credible individual experiences, but also sought to grasp larger social truths. These stories inadvertently began to operate on double and triple levels.... They attempted to capture the mutual relationship between the individual [vyakti] and the environment [pariveś] in its full complexity, or [in other words], this type of story became more profound, artistic, and impactful. Often two or three meanings resounded in them. They were superior stories of meaningful [sārthak] effort. (Yadav, Premacanda 98-99)

Using plain, minimalist prose, nayī kahānī fiction worked through images (bimb), which "have become the essential medium of artistic expression in the modern age" (N. Singh, Kahāni 33). Writers valued the image for its impressionistic, in-themoment presentism, through which it could instantaneously convey a story's underlying meanings (arth or sārthak) without authorial mediation. Aphoristically developing storylines through successions of descriptive imagery allowed nayī kahānī writers to express multiple levels (dharātal) of meaning simultaneously without falling into didacticism or judgment: as intellectual ideas, realistic depictions of ordinary events, and symbols of intersecting social, historical, and existential conditions 
(see Rakesh, Sāminkṛtik 38-39; N. Singh, Kahānī 32-33; Yadav, "Ek Duniyā" 67-69). Nayī Kahānī images wove fragmentary, yet detailed descriptions of characters' external landscapes with monologic reflections into their internal emotional lives, establishing a specific nayī kahānī equation for modernist realism: yathārth (reality) equals vyakti (individual) plus pariveś (environment). Through the instantiation of yathārth, nayī kahānī writers reached out to their readers, identifying with them on personal as well as circumstantial grounds.

I characterize yathārth as modernist realist because in formulating this mode, nayī kahānī writers conscientiously drew from and innovated upon the experimental modernist tradition represented by Agyeya and the progressivist realist tradition exemplified by Dhanpat Rai Srivastava "Premchand" (1880-1936) - both of which crystalized during the height of the Independence Movement. They described Agyeya's short stories as focused on emotional experience, philosophical reflection, and linguistic and formal innovation and praised his literary efforts "to cast aside plot-centered narratives, [enabling] feeling, thought, and [internal] conflict to take their place" (Yadav, "Kahānī” 26). Agyeya's work, in nayī kahānī writers' view, established a more personal connection with the reader, a feature that soon became central to the naȳ kahānī project (see Kamleshwar, Naȳ̄ Kahānī 12; Rakesh, Sāimskṛtik 46; Yadav, "Kahān̄̄” 26-27; Yadav, Kahānī 25, 46-47. For more on Agyeya's short-story writing, see Orsini, "Short Story").

However, nayī kahānī writers critiqued Agyeya's work for being so individualistic and philosophical that it unmoored the short story from material reality altogether, and for this reason, it was in Premchand's lineage that they ultimately situated their project. ${ }^{13}$ They characterized their commitment to yathārth as an innovation of Premchand's theorization of ādarśnmukhīyathārthvād, or idealistic realism, a literary methodology for exposing the material conditions of men and women's everyday lives in ways that imagined social change. In Premchand's view, the novel combined idealism with realism in order to reveal the naked truths of life while simultaneously entertaining and inspiring the reader. In this way, idealistic realism established the social function of literature wherein the writer aided the reader to feel compassion for characters' real-life circumstances and morally invest in their struggles for better material conditions. Novelists accomplished this literary aim by complementing detailed descriptions of character, plot, and setting with their own pedagogical or philosophical interpolations (see, for example, Premchand, Kuch Vicār 47-60; "Upanyās").

Premchand's essays on the short story reveal a slightly different understanding of the relationship between realism and idealism, however: "It would be a mistake to understand that the story is a realist portrayal of life.... Its uniqueness is precisely that it appears as reality even though it is not... The secret of art is delusion, but it is a delusion over which lies the veil of reality" (Kuch Vicār 32-34). Because of its highly constructed, terse, and bounded nature, Premchand held that the short story conveyed human truths through aesthetic insight, more so than emulative practice, thereby invoking sympathy (sahannubhüti) in readers when they otherwise may have felt none. For this reason, he viewed short-story truth as a kind of higher truth insofar as it was more fundamental to human experience than the superficial

13 For naȳ kahānī critiques of Agyeya's short story writing, see, for example, Yadav, "Ek Duniyā." 
truths gleaned through the sole depiction of mundane life. The short story established its own combination of realism and idealism whereby the writer drew in readers through the use of lifelike characters, plots, and settings, but inspired them through momentary revelations into human compassion, beauty, and intellect. Unlike the novel, it contained no room for authorial intervention. Instead, the writer elicited a sympathetic connection with the reader through in-depth focus on a singular event or character, carefully crafted descriptive detail, and linguistic subtlety $(b \bar{a} r \bar{k} k \bar{\imath})$. In these ways, the short-story genre remained committed to social change, but it achieved this change through more accessible and direct means than did the novel, which was a form requiring readers' time, money, and patience (Kuch Vicār 26-46).

The Premchandian short story thus moved away from the didacticism and classism associated with novelistic idealistic realism, and this was precisely why nayi kahānī writers turned to Premchand as their short-story forefather. They characterized a shift in Premchand's writing from his earlier, less-refined literary examinations of social realist character-types, such as the widow or the peasant, toward more nuanced depictions of dehumanization. These later portrayals formed what nayi kahānī writers called Premchand's samvedana drisți — what might be translated as his literary perspective or viewpoint (drisți) of sympathy, compassion, or sensitivity (samvedana). They understood his samvedana dṛisți as a mode - that is, as the manner through which the writer reached out to and established a meaningful relationship with the reader, catalyzing some measure of revelatory emotional or intellectual change in the reader's perspective. Nayī kahānī writers regarded this literary sensibility as their inheritance and calling to address and shape individual life (vyakti) in relation to external circumstance (pariveś) through fiction. Motivated by Premchandian writerly responsibility to society, naȳ kahānī writers presented modernist realist yathārth (reality) — that is, the perfectly poised illustration of personal and social experience - as striking the balance between realism and idealism that idealistic realism failed to achieve (see Kamleshwar, Nayi Kahāni 9-20; Rakesh, Sāinskṛtik 31-32; Yadav, "Kahān̄̄" 14-15; Yadav, Premacanda 85-92).

\section{Metaphor and Metonymy}

Yadav's “Śarat aura Premacanda” perfectly exemplifies this effort to integrate the progressivist realist emphasis on the social with the experimentalist modernist focus on the personal. By the standards of Western writers from Edgar Allan Poe to Ernest Hemingway, as well as Hindi critics such as Premchand and Namvar Singh, this story meets the requirements of a finely crafted story for several reasons: it focuses on a singular event and few characters using everyday conversational Hindi, contains no overt indication of the author's standpoint, employs imagery that operates on the levels of both realism and allegory, and ends with a twist as the narrator undergoes an unexpected change of heart. Most notable for the purpose of understanding nayī kahānī modernist realism, however, is the way in which it rhetorically employs these formal and thematic features to reference ongoing literary historical conversations of the time. The narrator draws the reader into the plot by slowly revealing the nature of his relationship with the woman who has left on the train, but only a reader knowledgeable about recent trends in contemporary 
Hindi fiction can glean its broader significance and self-reflexive irony, which otherwise read mainly on a realist plane.

The story's unraveling of the relationship between title and content most conspicuously marks the story's symbolic allusion to the metaliterary Hindi field. The connection of the title "Sarat aura Premacanda" to the narrative is never elaborated, but the typical middle-class Hindi reader would be aware that the title references two canonical writers who are integral to the development of modern Hindi: Premchand, whom I have discussed above, and the Bengali author Sharatchandra Chattopadhyay (1876-1938). For a nayī kahānī readership embedded in the literary discussions of the day, Premchand served as shorthand for a literary materialism saturated by human despair and dissolution. Sharatchandra, conversely, epitomized a literary sentimentalism $(b h \bar{a} v u k t \bar{a})$ manifested through star-crossed or unrequited romances, family feuds, and tragically flawed heroes. Prolifically translated into Hindi and popularized in both print and film, Sharatchandra's short stories and novels portrayed the psychologization of the human mind, and it was in this author's lineage that nayī kahānī writers placed Agyeya's focus on the individual (see, for example, Yadav, Kahāni 23-26). By juxtaposing Sharat and Premchand at its very outset, the story evokes the literary historical crossroads of the time: a stubborn tension between modernist sentimental individualism and realist social materialism, or in nayī kahānī terms, the polarization of vyakti (individual) and pariveś (environment). For example, any reader familiar with Sharatchandra's fiction would find Yadav's story reminiscent, particularly of Sharatchandra's famed Devdās. The eponymous hero of this 1917 novella becomes paralyzed by social prohibitions against marrying his childhood playmate and self-destructs as a result of his own despondency and inaction. The narrator of "Śarat aura Premacanda," caught in a similar situation, also appears locked in an emotional standstill, his intense desire to continue his romance excruciatingly at odds with existing norms against such liaisons. At the same time, the story alternates between the narrator's internal contemplation and a socially minded attentiveness to his external surroundings in typically Premchandian fashion.

These allusions caution against reading "Śarat aura Premacanda" as a halfhearted experiment with modernist individualism that ultimately gives way to social realist materialism and suggest, instead, that the story exemplifies an early nayī kahānī articulation of a synthesized modernist realism. The title alerts us to this reading by deliberately positioning the reader as an "insider," a literary historical interlocutor who is versed in the realist and modernist trends of the day and capable of understanding the narrator's literary references and the significance of his shifting focus between internal and external conditions. It lingers as a kind of contextualizing background, underscoring that at least two literary philosophies are at work in shaping the narrative. To an "outsider" unaware of Hindi literary debates, the narrator's musings might seem overly sentimentalized. But a reader aware of contemporary literary debates is encouraged to acknowledge an irony underlying the narrator's heartbroken exclamations, a sense that they in themselves do not constitute the central point of the story. The title forewarns the "insider" reader not to interpret the story solely in the vein of either Sharatchandra or Premchand. The narrator corroborates this sense each time he calls attention to the rickshaw driver's circumstances (e.g., on page 12) or angrily curbs his own 
emotional outpouring (e.g., 15). The concluding paragraph reconciles such externally motivated interjections with the narrator's internal stream of thought both literally - by combining the narrator's tears with the rickshaw driver's sweat-and figuratively-by searing a symbolically charged glistening bead of water in the reader's mind. Understood in the context of the dialogue between Sharat and Premchand that the title evokes, the shimmering drop evidences the new, more integrated reality ( $y$ athārth) that the Nayī Kahānī Movement sought to develop within the field of Hindi fiction.

Put differently, in encapsulating the nayī kahānī merging of vyakti with pariveś, the water drop simultaneously maintains metonymic contiguity with external reality as well as metaphoric similarity to recognizable ulterior realities or truths. ${ }^{14}$ Constant oscillation between the narrator's inner consciousness and his surrounding environment enables the narrative metonymically to create a realist aura of contemporary circumstances while at the same time metaphorically referencing existing metaliterary debates about realism, modernism, and the function of literature in society. The story's multiple references to the North Indian landscape and its existing social mores make it representative of Hindi readers' everyday experience. Concurrently, the narrator's varying attention to his internal and external conditions allegorizes the literary historical contest between Sharat and Premchand. Metaphor, in this case, functions "figurally": the water drop is, in Auerbach's words, "something real and historical which announces something else that is also real and historical. The relation between the two events is revealed by an accord or similarity" ("Figura" 29).

In this way, the water drop instances the imagistic presentism of the nayī kahānī, what Rakesh calls the "harmony of image and idea-that is, the assembling of the image such that the idea explodes from within it, characters and events presented in the form of such tangible portrayals that the image itself illuminates the author's intention or symbol" (Sämskrtik 38). As metonymic detail, the water drop brings readers proximate to the narrator's situation. It operates in conjunction with the story's other descriptions of landscape to enlist readers in the narrator's present environment and desires, linking his personal situation to a recognizable social topography. At the same time, as allegorical symbol, the water drop ironically suggests Yadav's own frustration with the limits of existing social realist and modernist literary methods without imposing any one decisive message. Rather, it asks readers to participate in and develop their own verdict on the realism-modernism debate, placing them on literary par with Yadav himself.

\section{From Sympathy to Empathy}

The water drop in "Śarat aura Premacanda" can be situated within a broader nayī kahānī discourse of empathy that established an interchangeability between the positions of reader, narrator, and author. Using such images, writers sought to enable readers to feel with, rather than for, the characters and the author, thereby

14 See Jakobson ("Two Aspects"), for discussion of the metonymic and metaphoric poles of language, wherein metonymic detail constitutes the realism of prose and metaphoric substitution, the abstraction of poetry. 
identifying with the tensions and uncertainties of the postindependence present (see Keen for discussion of the terms sympathy and empathy). This form of empathywhat, Yadav writes, is "not sahānubhūti [sympathy], but sah-anubhüti [shared feeling]" ("Kahān̄̄" 27) — operated antithetically to idealistic realism (ädarśonmukhi yathārthvād). ${ }^{15}$ The Premchandian realist mode was effective insofar as the writer invoked sympathy in readers toward characters' unjust living conditions, motivating them to work toward achieving a more utopian society. ${ }^{16}$ Nayī kahānī empathy, by contrast, sought to kindle fleeting moments of human connection between individuals and their environment. Rather than morally instigating readers to create social change, nayī kahānī empathy captured modern sensibilities such as alienation, disconnection, and disillusionment. It entreated readers to recognize their own circumstances from the position of an "other," to detachedly relive their individual experiences through the medium of literature (see, for example, Kamleshwar, Naȳ Kahān̄ 17; Yadav, Mud-Mudke 31-37).

Mohan Rakesh's well-known story "Mis Pāl” ("Miss Pal," 1961) nicely illustrates how naȳ kahānī empathy sought to inculcate a sense of alienation in readers. "Mis Pāl" examines the lonely life of its eponymous character through the eyes of the narrator, Ranjit - a friend and former colleague who runs into Miss Pal after she has left her Delhi job to live in a remote village in the Kullu Valley. Ranjit sees Miss Pal as a misfit in every way: fat, flamboyant, awkward, unmarried, unmotivated, and sometimes hypocritical and irritating. Despite all these qualities, however, Ranjit feels some connection with Miss Pal: "Often Miss Pal received us with great sadness and couldn't even converse with us properly. My sisters would get irritated with her at such moments.... Yet, it was at these times that I felt the greatest sympathy [sahānubhūti] for Miss Pal" (Rakesh, "Mis Pāl” 11). Miss Pal's blundering social graces evoke the stirrings of compassion in Ranjit, driving him to try to better understand Miss Pal's circumstances and what she will do now that she has left Delhi. So, when he catches a passing glimpse of her from his bus window while traveling through Kullu, he immediately turns back to meet her.

Ranjit's initial sympathy for Miss Pal quickly devolves, however, into a less steadfast, more ambiguous sense of human connection, which the story conveys through the interweaving of the characters' internal emotions with the surrounding landscape in a manner similar to "Śarat aura Premacanda." The view of the mountains and clouded horizon, for instance, fills in the gaps and silences in the awkward conversations between them:

It was nearly a full moon, and moonlight spread across the sky in all directions. The sound of the Byas River created a roar in the atmosphere. Apart from the rustling trees, a dim rustling also arose from the grassy field. The wind was fierce and the clouds rising behind the mountains ahead glided slowly toward the moon. (Rakesh, "Mis Pāl” 22)

15 The Hindi word sahānubhūti and its synonyms ( samvedana, hamdard̄̄) indicate both sympathy as well as empathy. No Hindi word solely signifies empathy. Yadav thus has to coin one by separating the word sahänubhüti into its etymological components: sah-, a prefix meaning "shared," and anubhüti, a feminine noun meaning "perception" or "feeling."

16 See Gajarawala, Untouchable Fictions 45-48; and A. Rai. Gajarawala demonstrates that Premchandian sympathy "performed the crucial function of consolidating uppercaste identity" (46). I would also add that Premchandian sympathy began the process of conjoining upper-caste with middle-class identity, which the naȳi kahānī emphasis on empathy would later complete. 
Moved by this sonorous setting, Ranjit asks Miss Pal why she seems so contemplative. "Miss Pal looked into the misty line of mountains, as if she were looking for something. 'I think, Ranjit, my life has no meaning. ... Only I know the difficulties I've had till now preserving my um ...uh ... purity"' (22); she sighs, delicately acknowledging that her alienation has been due largely to her unmarried status. When Ranjit suggests that she focus on making art, Miss Pal evades Ranjit's probing questions, and the atmospheric mood shifts. Suddenly, the conversation is barraged by human voices, and a roaring breeze usurps the gentle sound of the river and causes the two friends to shiver. Clouds cloak the moon, and the nearby cottages extinguish their lights, abruptly resolving Ranjit and Miss Pal's conversation in silence and disconnection.

Just as the mountain-scape charts Ranjit and Miss Pal's dissipating relationship, Miss Pal's disarrayed domestic landscape maps her eccentric interiority. Ranjit expresses frustration as he describes his visit to her cottage, filled as it is with heaps of clothing and junk. Anxious to leave but wrought by guilt, he makes a desperate attempt to draw Miss Pal out of her depression by convincing her to join him on his bus ride back to Kullu, where he can go onwards to Delhi and she can buy art supplies. She reluctantly concedes, but in the final scene of the story, as the two friends wait at the bus stand, Miss Pal is dissuaded:

Two little girls were quietly conversing amongst themselves, "It's a man."

"No, it's a woman."

"Look at her hair and the rest of her body. It's a man."

"Look at her clothes, at everything. It's a woman."

"Come here, kids, come closer and take a look," [said Miss Pal]. I was surprised by Miss Pal's voice. Miss Pal had just returned from the counter with a bus ticket.... But the kids ran even further away instead of coming closer. Miss Pal stood for a moment in the middle of the road and then turned back to me. The expression on her face was quite strange. The tears welling up in her eyes were about to tumble down and she tried to give a meek laugh to conceal them. She had bitten at her lip somehow so that her lipstick was halfway smeared underneath. The stitching on her worn-out shirt was unraveling at the shoulder.... The bus was starting up, and I peered through the window at Miss Pal. As the bus departed, Miss Pal began to wave. She was carrying two empty containers [for supplies] in her hands. I waved a hand back at her once and watched those swinging empty containers until the bus turned away. (26-27)

Ranjit's effort to rescue Miss Pal from her lonely, slovenly existence fails. The vanishing sight of the empty swinging containers creates a sense of helplessness, hollowness, ambivalence. The story conveys estrangement doubly - through Miss Pal, whose hopeless isolation readers encounter through Ranjit's eyes, and through Ranjit, whose bond with Miss Pal is just as tenuous and fleeting as is ours. Both are ultimately alone, disconnected from and disillusioned by the world around them. Ranjit's narratorial shuttling between dialogue and descriptions of the surrounding mountain and domestic environments - in short, the narrative's use of outer reality to express the inner realities of the characters-enables these emotions to resonate within readers. It compels readers to feel with, rather than for, the characters, offering little resolution to the condition of modern alienation.

Indeed, it is Ranjit's presence as the mediating narrator that transforms earlier, Premchandian sympathy into naȳ kahānī empathy. Rakesh's Miss Pal emerges as a postindependence metamorphosis of Premchand's well-known character Miss Padma, the protagonist of his eponymous story (1936), written in the third person. Both Miss Pal and Miss Padma are westernized, educated, economically independent, unmarried women. Miss Padma, however, makes a commitment to her 
companion Prasad, who shares her belief in free love and individual choice. The two live together out of wedlock, agreeing to share everything and be faithful to one another. Sadly, though perhaps also predictably, Prasad runs off with another woman, and Miss Padma is left pregnant and alone. The ending of Premchand's story echoes that of Rakesh's. One day Miss Padma catches sight of a couple walking down the street and is reminded of Prasad. Premchand concludes, "She watched the happy couple longingly and her eyes filled with tears" ("Mis Padmā" 62). Like Miss Pal, Miss Padma finds herself abandoned, empty-handed, and at a loss. The difference, however, is that in Rakesh's story, Ranjit forlornly observes the unfulfilled Miss Pal, while in Premchand's story, Miss Padma mourns a conjugal life she cannot have. Without the distancing mediation of a first-person narrator like Ranjit with whom readers may (or may not) identify, the omniscient thirdperson narration in "Mis Padmā" implores them to feel sympathy for the protagonist and desire to reform the social circumstances that have led to her situation. Ranjit, by contrast, provides a position from which to relate to Miss Pal, revealing to readers that Miss Pal, while equally invested in free love and individual freedom as Miss Padma, cannot sustain relationships with men or women-just as Ranjit himself and, by extension, his readers seem unable to sustain them. Whereas Miss Padma's story recounts the impractical binds of nontraditional and extramarital relationships, Miss Pal's tells of the limitations of interpersonal connection. Of course, these limitations are due in part to Miss Pal's unfettered, somewhat androgynous sexuality and eccentricity. However, they also seek to articulate the general alienated condition of individuals in the postindependence moment, a central theme through which nayī kahānī fiction aimed to consolidate its vision of a universally inclusive middle class.

\section{Destabilizing the New Woman}

The addition of an aloof first-person narrator is one way in which the nayī kahānī, taking a cue from the experimental modernist (prayogvādī) tradition's literary focus on psychological experience, innovated the Premchandian short-story form. Through this literary device, just as through irony, imagistic symbolism, and descriptions of landscape, writers commented upon modern man-woman relationships. In contrast to the Premchandian story's use of the new woman as a vehicle for, or site upon which to mobilize, social reform, the nayī kahānī explored her troubled existence as the symbolic manifestation of contemporary reality (yathārth) the unique combination of individual experience (vyakti) and social environment (pariveś) that characterized postindependence life. In the case of "Mis Pāl," Rakesh appeals to readers to fathom their own postcolonial discontent through Ranjit's voyeuristic empathy of Miss Pal's awkward womanliness and resulting social exclusion. His narratorial voice adds another layer (dharātal) of meaning that moves readers beyond the disillusionment with social circumstances that Miss Padma experiences toward a sense of irresolvable, personal disconnection from the world.

Altering the short-story genre through such devices, nayī kahānī writers created a new formal relationship to the new woman that destabilized common preindependence representations of women characters as either bearers or transgressors of tradition. In the past, "the problem of woman signified [a kind of] deformed 
compassion or indistinct profanity, in reaction to which woman was generally adorned with infinite power, mystery, and physical splendor and turned into a virulent rebel against social and ethical values. That is, she was never, in any situation, normal" (Bhandari, "Is Annk" 5). Woman was a character-type-goddess, mother, grandmother, daughter, sister, sister-in-law, or prostitute - a figure requiring patriarchal compassion, protection, or reform. But, "woman's body is now the object of her own decision-making. No longer is cheating, rape, or the mental brutality of the perverse sister/sister-in-law tradition a topic of writerly sympathy [sahānubhūti]" (Kamleshwar, Naȳ Kahānī 19). Instead, the nayī kahānī sought to place women on more equal footing to men. It examined the freedoms of a woman who "is selfearning and sits down at the same table [as men] to work, a woman who partakes in one's happiness, sadness, amusement, and worry like a friend, a woman-friend who insists that her relationship is not defined by any pre-existing labels" (Yadav, Kahāni 59). In doing so, writers transfigured the short-story genre, as much as the man-woman relationship form. As Mannu Bhandari stressed in her preface to the May 1963 issue of the journal Naī Kahaniyām that she guest-edited, the stories she selected for inclusion transformed the "problem of woman" into a question of aesthetics:

I believe that woman is not set apart as some sort of "theorem" or "problem" that a bunch of men sit around and get pleasure from solving. If her responsibilities and expectations really are the same as a man's, then no problem of hers is hers alone, rather it is a problem of life in its entirety.... Thus, if the short story of today, with all of its artistic achievements, portrays the equal relationship of man and woman from an actual realistic perspective, then it is definitely not indifferent to this problem. As such, the stories in this issue most certainly present several of the most important circumstances of contemporary life, and they should be read ... as independent, artistic short story units. This perspective is what I hope to have achieved as editor of this issue. ("Is Añk" 5)

In other words, the nayī kahānī sought to realistically portray problems arising within modern gender relations just as preceding short story trends had done, but the significance of these problems lay in their broader artistic presentation, rather than in narrow ideological handiwork.

Bhandari’s story “Abhinetā” (“Actor,” 1957) playfully demonstrates how the nayī kahānī reconfigured the man-woman relationship on more equal terms through the disruption of prevailing short-story conventions. The story begins with a description of the protagonist Ranjana: "She was a hugely successful and extraordinary actress, an expert in her art" ("Abhinetā" 71). The narrator then immediately interjects:

But wait! The beginning of this story is already wrong. I titled the story "Actor" and started with an "actress." It seems that for those of my kind, what happens to be a natural weakness of the mind has become habit. And since I've already taken the first step, onward will I now continue. Yes, with the hope that some actor [willing to] sacrifice himself wholeheartedly for the art and beauty of this actress of mine will certainly come along. (71)

The subject of the narrator's story, an actress, does not match the title she has given it, "Actor." In referring to her natural weakness, she implies that this blunder is the result of her second-rate standing as a (woman) writer. ${ }^{17}$ Almost as if to challenge

17 Just two women writers - Krishna Sobti (1925-2019) and Usha Priyamvada (b. 1930) — have been counted alongside Bhandari among the ranks of nayī kahānī writers. However, only Bhandari participated in the otherwise all-male discussions that came to define the movement. I have elsewhere 
those who would place her in an inferior position however, she continues, hoping that her narrative will eventually evolve into the story of the actor suggested by her title. The narrator's interpolation presents the primary problematic of the story: whether or not the story's content will suit its title and thereby also its form. In a similar manner to Yadav's "Śarat aura Premacanda," Bhandari's story uses the seeming dissociation between title and content to reconsider the status of its subject matter-in this case, the actress, a common type of prostitute figure - within the Hindi short-story tradition. ${ }^{18}$

The tension between form and content in Bhandari's "Abhinetā" stands out more starkly if we place it in conversation with Premchand's "Aikțres" ("Actress," 1927). Bhandari's Ranjana shares several uncanny similarities with this story's protagonist, Tara. Ranjana is successful in her professional life but a failure in her personal life and, like Tara, desires nothing more than to meet a man willing to sacrifice himself wholeheartedly to her. Both actresses meet the men of their dreams and receive marriage proposals from them. But then the stories diverge: Premchand's Tara comes to the realization that she is not suitable for her would-be husband. While he is of simple mind and open heart, she is an actress, a worldly woman of wily charms and the mistress of many men. Unable to overcome her feelings of guilt and inferiority, on the eve of her civil-union ceremony, Tara slips off into the night dressed in widow's garb and sets sail across the Ganges "like someone wandering into the kingdom of dreams" (168). The story thus points an accusing finger at the social prohibition against marriage between an actress and a gentleman, but it does not overstep this norm, instead portraying Tara as a self-sacrificing woman, while leaving her future enigmatically open.

Ranjana's story follows a different trajectory. When she first meets her would-be husband, Dilip, Ranjana finds that he objects to the profession of acting as a whole, equating the pretense of acting with the actor's inherent demeanor in real life. Despite this indictment, however, the two begin a courtship, and eventually Dilip proposes to marry Ranjana as soon as his business gains financial stability. At this moment, the narrator again intervenes wittily: "My heart is sinking. The possibility of Dilip becoming an actor was remote, and Ranjana was also prepared to give up the acting profession. And I'm thinking that if these people's conduct remained this way, then what will happen to my title?" (Bhandari, "Abhinetā" 78). In Premchand's story, the prospect of marriage causes the plot to turn toward tragedy and the trumping of desire by womanly propriety. Here, the narrator points out that the more important impending tragedy is her own possible failure to write the story about an actor that she had initially set out to write. Hers is a tragedy of genre, not just of human connection.

demonstrated how Bhandari used a unique language of entitlement in her fiction to depict female protagonists who possess as much desire for sexual expression, economic independence, and human equality as their male counterparts do. In doing so, Bhandari portrayed characters that transgress the norms of acceptable womanly propriety by couching feminine desire in the terms of alienation, disconnection, and disillusionment, which were so definitive of the naȳ kahānī aesthetic. See Mani, "Feminine Desire." Similarly, in "Abhinetā," Bhandari's female narrator legitimates her sense of writerly entitlementsomething not often or easily accorded to women writers of her time-by articulating it using the conventions of naȳ kahānī modernist realism.

18 See Bhatia for discussion of how the figure of the actress became associated with prostitution in late nineteenth-century North India. 
When Dilip sets off on a few weeks of travel and fails to return, Ranjana stops by his house and discovers a stack of love letters from another woman, quite possibly his wife. Ranjana's world is now completely turned upside down, and her last act in the story is to leave Dilip a letter of her own. She writes: "Dilip, well, I act only on stage, but your whole life is an act. It is you who are the greatly esteemed artist and practiced actor, my friend!-Ranjana" (Bhandari, "Abhinetā" 82). The narrator then closes the story with the following lines: "I don't know what happened to Ranjana or Dilip after this. I'm just happy about the fact that the title of my story has become meaningful" (82).

These concluding lines, and the narrator's interpolations more generally, uphold the tragic arc of Premchand's "Aikțres" - whereby both actresses are denied entrance into the sanctioned conjugal fold-while also reconfiguring his story in two important ways. First, they successfully, if ironically, establish Ranjana on the same moral playing field as Dilip. Ranjana ultimately emerges not as Dilip's wife, mistress, or prostitute, but rather as a human being who deserves happiness and love as much as anyone else. Premchand's Tara talks herself out of marriage, believing she is unworthy, while in Bhandari's story, the fault lies with Dilip.

Secondly, the narrator adds a meta-narrative about form to the fateful actress/ gentleman relationship, questioning the limitations of modern gender relations (as well as the authority of the male canon) through the destabilization of the short story genre itself. In Premchand's story, although the decision to slip away before marriage is Tara's alone, it arises out of the particular confines of her social circumstances, which disallow transgression of the traditional conjugal relationship. Ranjana's abandonment, conversely, emerges not only from an environment in which the actress-gentleman relationship is taboo, but also because of the conventions of genre, which demand the harmony of form and content. When the narrator's desire to fulfill the requirement of her title comes to heads with Ranjana's desire to marry despite her status as an actress, the narrator necessarily wins out, illustrating how the constrained position of the new woman has become the very condition of authorship in the postindependence moment. Ranjana is forsaken like all prostitutes and independent women before her. However, as the narrator of "Abhinetā" shows, depicting the fraught figure of the new woman caught between tradition and modernity is no longer enough to enable literature to accrue social relevance. If this were the case, then Premchand's narratives would have continued to suffice. Rather, the narrator's explicit use of the new woman in "Abhinetā" to resolve a problem of authorship ironically points to the overwrought use of this trope, asking readers to invest instead in a new reality, one delimited by literary and not just social norms.

\section{The Newness of Modernist Realism}

Nayī kahānī modernist realism was not merely formal or thematic, although it certainly facilitated unprecedented experiments with form and content. Its contribution was rhetorical and therefore aimed at creating social change. For nayi kahānī writers, this meant reconfiguring the category of the middle class using the more universally recognizable terms of alienation, disconnection, and disillusionment. In her discussion of Premchand's "Aiktres," Nandi Bhatia argues that Tara's "decision to leave at the end so that marriage can be avoided can be read 
as ... reinforc[ing] codes of socially appropriate behavior for middleclass women and men" (21). Although Dilip's disapproval of the acting profession suggests that similar codes of middle-class propriety operate in Ranjana's context as well, "Abhinetā" marks a key shift in how naȳ kahānī writers conceived of the middle class in contrast to Premchand: Ranjana sees herself as part of the middle class in a way that Tara simply cannot. She enlists the reader to identify with her desire for marriage by articulating it through feelings of rejection and unbelonging. The narrator reframes Ranjana's emotional response as a question of aesthetics, reminding readers that the current conceptualization of the middle class-too exclusive for actresses like Tara and Ranjana to find a place-is outdated and suggesting that any attempts to disband it must begin in the literary imagination.

The newness of nayī kahānī modernist realism, then, lay in the way it brought readers into its vision of the middle class. Enabling an interchangeability between author, reader, and character that did not previously exist within the Hindi canon, nayī kahānī modernist realism transformed Premchand's idealistic realism into an imagistic presentism, its discourse of sympathy into a discourse of empathy, and its social reformist critique of gender relations into a destabilization of form. Through these rhetorical devices, nayī kahānī writers introduced a sensibility of alienation that linked individual experience (vyakti) to postindependence social circumstances (pariveś), producing a reality (yathārth) that positioned the reader to view the North Indian landscape from their secular, cosmopolitan perspective. Nayi kahānī writers thus addressed and negotiated-however directly or indirectlyglobally circulating discussions of philosophical existentialism, national concerns regarding Partition and decolonization, and regional Hindi literary debates about social realism and experimental modernism.

By figuring the authorial persona no differently than nayī kahānī characters and readers, modernist realism aspired to produce an equalizing relationship between authors and readers, constructing reality as relative to each individual's experience, yet also relatable across a wide range of experiences. In doing so, this mode stipulated a new type of authorial entitlement that rested in the writer's depiction of those experiences that he or she had personally endured. Nothing less could be real. While this notion of authorial legitimacy may seem commonplace today, I want to stress the novelty of modernist realism for shaping Hindi readerships in the immediate postindependence context. Until it emerged, anyone could write about anyone else. Premchand's authority to portray the struggles of women and lower-caste and out-caste peasants and laborers was, therefore, uncontested in the late colonial Hindi sphere, when such depictions were unprecedented. By questioning the validity of this authority, nayī kahānī empathy consolidated a class politics that refracted identitarian difference through the shared experience of individual alienation.

Not surprisingly, subsequent literary movements have critiqued the naȳ kahānì middle-class vision's claim to universality, demonstrating its contradictory elisions of class, caste, religion, and gender in varying ways. However, they have also continued to draw on the politics of representation that its modernist realism put in place. One notable example is Hindi Dalit literature - itself a relatively new body of writing focusing on "untouchable" caste identity and oppression. Recent scholarship has argued that the Dalit corpus's insistence on Dalit authorship, focus on the 
short story, attention to metonymic detail, and rendering of national-scale events such as Partition in inconsequential terms stems from Dalit literature's politics of resistance to upper-caste nationalism typified by the novel form (Brueck; Gajarawala, Untouchable). Social oppression and marginalization from accepted mediums of self-representation undoubtedly shape Dalit literary resistance. Yet Dalit literature is not just a political project. It is also, as this scholarship has expressed, a literary one. What I hope to have demonstrated through my examination of the nayi kahānī is that understanding the ways in which Dalit literature, or any other corpus, participates in literary production-how it arises out of and in response to, dialogues with, and also revises and directs the aesthetic dispositions of the Hindi literary sphere-requires a literary historical lens. The Nayī Kahānī Movement's privileging of the short story, oblique treatment of Partition, and insistence on locating individual experience within larger social circumstances provides a literary historical background upon which to locate Dalit realism. As the narrator of Yadav's 1954 story "Yathārthvādī Kahānì-Lekhak" ("The Realist Short Story Writer") anticipates, "Peasants and laborers ... will produce their own literature someday" (54). It is perhaps no surprise that in the 1990s, Yadav turned his literary magazine Hams into a platform for Hindi Dalit writing, debuting the work of several now well-established Dalit authors at a moment when no other editors would publish them.

Let me be clear, however, that in demonstrating the ways in which nayī kahānī writers provided explicit interpretations of their own project, I am not arguing that they possessed a privileged vantage point toward their writing or heightened ability to see the world in a way that others could not. I have sought to illuminate, instead, how the Nayī Kahānī Movement combined literary texts with metaliterary ones to critically intervene in the Hindi literary field. The literary historical imaginary that its writers developed is not, therefore, determinative of how their fiction has to be read. Rather, it provides insight into how the movement aspired to recruit readers into a particular aesthetic community. Naȳ̄ kahānī modernist realismfashioned by a persistent back-and-forth between literary and metaliterarycompels us to see how focusing on "representative texts" from any given tradition may not provide enough footing for understanding how literary modes operate. We may need to expand our reach into the literary historical before we can define the "traditional methods of narrative representation" to which Jameson refers and in relation to which realisms and modernisms everywhere take shape.

Rutgers University, New Brunswick

\section{References}

Adorno, Theodor, Walter Benjamin, Ernst Bloch, Bertolt Brecht, Georg Lukács. Aesthetics and Politcs. 1977; repr., New York: Verso, 2007.

Agyeya, ed. Dūsra Saptak (The Second Octave). 1952; repr., New Delhi: Bharatiya Jnanpith, 1996.

Agyeya, ed. Tār Saptak (The Upper Octave). 1943; repr., New Delhi: Bharatiya Jnanpith, 1995.

Ahmad, Aijaz. "In the Mirror of Urdu: Recompositions of Nation and Community, 1947-65." In Lineages of the Present: Ideology and Politics in Contemporary South Asia, 103-25. New York: Verso, 2000. 
Ahmed, Talat. Literature and Politics in the Age of Nationalism: The Progressive Writers' Movement in South Asia, 1932-1956. London: Routledge, 2009.

Anjaria, Ulka. Realism in the Twentieth Century Indian Novel: Colonial Difference and Literary Form. Cambridge: Cambridge University Press, 2012.

Ansari, Dagmar. "Changes in the Hindi New Short Story of the 1960's." Archiv Orientalni 43 (1975): $33-52$.

Ansari, Dagmar. "Indian Social Reality of the Early 1960s as Reflected in Hindi New Short Story.” Archiv Orientalni 42 (1974): 289-299.

Ashk, Upendranath. Hindi Kahānī: Ek Antaraing Paricay (The Hindi Short Story: An Intimate Survey). Allahabad: Nilabh, 1969.

Auerbach, Erich. "Figura." In Scenes from the Drama of European Literature, translated by Ralph Maheim, 11-76. Minneapolis: University of Minnesota Press, 1984.

Auerbach, Erich. Mimesis: The Representation of Reality in Western Literature, translated by Willard R. Trask. Princeton: Princeton University Press, 2003.

Awasthi, Devishankar, ed. Naȳ Kahānī: Sandarbh Aura Prakrtī (The New Story: Context and Nature). Delhi: Akshar, 1966.

Bakhtin, Mikhail. The Dialogic Imagination: Four Essays, translated by Caryl Emerson and Michael Holquist. Austin: University of Texas Press, 1981.

Bakhtin, Mikhail. "The Problem of Speech Genres.” In Speech Genres and Other Late Essays, edited by Caryl Emerson and Michael Holquist, translated by Vern W. McGee, 60-102. Austin: University of Texas Press, 1986.

Barthes, Roland. "The Reality Effect." In The Rustle of Language, translated by Richard Howard, 141-48. Berkeley: University of California Press, 1984.

Bhandari, Mannu. "Abhinetā” (“Actor”). In Maìm Hār Gā̄ (I Lost), 71-82. New Delhi: Radhakrishna, 2001.

Bhandari, Mannu. Ek Kahān̄̄ Yah Bhī (This Too Is a Story). New Delhi: Radhakrishna, 2007.

Bhandari, Mannu. "Is Añk Ke Bāre Mẹ̣” ("About This Issue”). Naī Kahāniyā̇̀ 4, no. 1 (1963): 5.

Bhatia, Nandi. Performing Women/Performing Womanhood. Oxford: Oxford University Press, 2010.

Brueck, Laura. Writing Resistance: The Rhetorical Imagination of Hindi Dalit Literature. New York: Columbia University Press, 2014.

Casanova, Pascale. The World Republic of Letters, translated by M. B. DeBevoise. Cambridge, MA: Harvard University Press, 2004.

Damsteegt, Theo. "Ajneya and the New Short Story in Hindi." Journal of South Asian Literature 21, no. 2 (1986): 217-29.

Damsteegt, Theo. "The Early Short Stories of Mohan Rakesh.” Journal of South Asian Literature 19, no. 1 (1984): 141-55.

Damsteegt, Theo. "Mohan Rakes and Literary Hindi." Studien zur Indologie und Iranistik 8-9 (1982): 97 111.

de Bruijn, Thomas. "Impostors in the Literary Field: Aspects of Characterization in Nayi Kahani." In Heros and Heritage: The Protagonist in Indian Literature and Film, edited by Theo Damsteegt, 127-45. Leiden: Leiden University Press, 2003.

de Bruijn, Thomas. "Nirmal Varma: A Hindi Author on the Shores of Modernity." IIAS Newsletter 26 (2001): 24-25.

de Bruijn, Thomas. "Under Indian Eyes: Characterization and Dialogism in Modern Hindi Fiction." In Chewing over the West: Occidental Narratives in Non-Western Readings, edited by Doris Jedamski, 183-212. Amsterdam: Rodopi, 2009.

Deshpande, Satish. Contemporary India: A Sociological Perspective. London: Penguin, 2003.

Deshpande, Satish. "Mapping the 'Middle': Issues in the Analysis of the 'Non-Poor' in India." In Contested Transformations: Changing Economies and Identities in Contemporary India, edited by Mary John, Pravin Jha, and Surinder Jodhka, 215-36. New Delhi: Tulika, 2006.

Doyle, Laura, and Laura Winkiel. Geomodernisms: Race, Modernism, Modernity. Bloomington: Indiana University Press, 2005. 
Esty, Jed, and Colleen Lye. "Peripheral Realisms Now." Modern Language Quarterly 73, no. 3 (2012): 270-87.

Fernandes, Leela. India's New Middle Class: Democratic Politics in an Era of Economic Reform. Minneapolis: University of Minnesota Press, 2006.

Friedman, Susan Stanford. "Definitional Excursions: The Meanings of Modern/Modernity/Modernism.” Modernism/Modernity 8, no. 3 (2001): 493-513.

Friedman, Susan Stanford. "Periodizing Modernism: Postcolonial Modernities and the Space/Time Borders of Modernist Studies." Modernism/Modernity 13, no. 3 (2006): 425-43.

Friedman, Susan Stanford. "Planetarity: Musing Modernist Studies.” Modernism/Modernity 17, no. 3 (2010): 471-99.

Frye, Northrop. Anatomy of Criticism. Princeton: Princeton University Press, 1957.

Gajarawala, Toral Jatin. "The Casteized Consciousness: Literary Realism and the Politics of Particularism.” Modern Language Quarterly 73, no. 3 (2012): 329-49.

Gajarawala, Toral Jatin. Untouchable Fictions: Literary Realism and the Crisis of Caste. New York: Fordham University Press, 2013.

Genette, Gerard. The Architext: An Introduction, translated by Jane E. Lewin. Berkeley: University of California Press, 1992.

Genette, Gerard. Narrative Discourse: An Essay in Method, translated by Jane E. Lewin. Ithaca: Cornell University Press, 1980.

Gikandi, Simon. "Preface: Modernism in the World." Modernism/Modernity 13, no. 3 (2006): 419-24.

Gikandi, Simon. "Realism, Romance, and the Problem of African Literary History." Modern Language Quarterly 73, no. 3 (2012): 309-28.

Jakobson, Roman. "On Realism in Art." In Language in Literature, edited by Krystyna Pomorska and Stephen Rudy, 19-27. Cambridge, MA: Belknap, 1987.

Jakobson, Roman. "Two Aspects of Language and Two Types of Aphasic Disturbances.” In On Language, edited by Linda R. Waugh and Monique Monville-Burston, 115-33. Cambridge, MA: Harvard University Press, 1990.

Jalil, Rakhshanda. A Literary History of the Progressive Writers' Movement in Urdu. Oxford: Oxford University Press, 2014.

Jameson, Fredric. “Antinomies of the Realism-Modernism Debate.” Modern Language Quarterly 73, no. 3 (2012): 475-85.

Jameson, Fredric. The Antinomies of Realism. New York: Verso, 2013.

Jameson, Fredric. The Political Unconscious: Narrative as a Socially Symbolic Act. 1981; repr., London: Routledge, 1983.

Kamleshwar. Naȳ̄ Kahān̄̄ Kì Bhūmikā (Introduction to the New Story). Delhi: Akshar, 1966.

Kapur, Geeta. When Was Modernism: Essays on Contemporary Cultural Practice in India. New Delhi: Tulika, 2000.

Kaviraj, Sudipta. “On State, Society and Discourse in India." In Rethinking Third World Politics, edited by James Manor, 72-99. Harlow, UK: Longman, 1991.

Keen, Suzanne. "Narrative Empathy." In The Living Handbook of Narratology, edited by Peter Hühn. Hamburg: Hamburg University Press, 2015. hup.sub.uni-hamburg.de/lhn/index.php?title=Narrative_ Empathy\&oldid=2044.

Krishnan, Sanjay. "V. S. Naipaul and Historical Derangement." Modern Language Quarterly 73, no. 3 (2012): 433-51.

Kumar, Sukrita Paul. The New Story: A Scrutiny of Modernity in Hindi and Urdu Short Fiction. Shimla: Indian Institute of Advanced Studies, 1990.

Lazarus, Neil. The Postcolonial Unconscious. Cambridge: Cambridge University Press, 2011.

Lotz, Barbara. "Rāhom Ke Anveși: The Editor of the Saptak Anthologies and His Poets." In Hindi Modernism: Rethinking Agyeya and His Times, edited by Vasudha Dalmia, 125-46. Berkeley: Center for South Asian Studies, University of California, 2012.

Lukács, Georg. The Meaning of Contemporary Realism. London: Merlin, 1962. 
Lukács, Georg. The Theory of the Novel: A Historico-Philosophical Essay on the Forms of Great Epic Literature, translated by Anna Bostock. Cambridge, MA: MIT Press, 1971.

Lukács, Georg. “To Narrate or Describe.” In Writer and Critic, translated by Arthur Kahn, 110-48. London: Merlin, 2007.

Madhuresh. Hind̄̄ Kahānī Kā Vikās (The Development of the Hindi Short Story). Allahabad: Lokbharati, 1996.

Mani, Preetha. "Feminine Desire Is Human Desire: Women Writing Feminism in Postindependence India." Comparative Studies of South Asia, Africa and the Middle East 36, no. 1 (2016): 21-41.

Mani, Preetha. The Idea of Indian Literature: Gender, Genre, and Comparative Method. Forthcoming.

Mukherjee, Meenakshi. Realism and Reality: The Novel and Society in India. Oxford: Oxford University Press, 1985.

Orsini, Francesca. "Konrad Meisig, Erzähltechniken Der Nayī Kahān̄̄." Indo-Iranian Journal 41, no. 1 (1998): 82-87.

Orsini, Francesca. “The Short Story as an Aide À Penser: Ajñeya’s Stories.” In Hindi Modernism: Rethinking Agyeya and His Times, edited by Vasudha Dalmia, 103-23. Center for South Asian Studies, University of California, Berkeley, 2012.

Parry, Benita. “Aspects of Peripheral Modernism.” ARIEL 40, no. 1 (2009): 27-55.

Prakash, Bodh. Writing Partition: Aesthetics and Ideology in Hindi and Urdu Literature. London: Pearson Longman, 2009.

Premchand. "Aikțres” (“Actress”). In Mānasarovar, Bhāg 5 (Manasarovar, Volume 5), 161-68. Patna: Anupam, 2011.

Premchand. Kuch Vicār (Some Thoughts). Allahabad: Saraswati, 1985.

Premchand. "Mis Padmā" ("Miss Padma"). Mānasarovar, Bhāg 2 (Manasarovar, Volume 2), 58-62. Patna: Anupam, 2011.

Premchand. "Upanyās" ("The Novel”). In Vividh Prasaing (Various Matters), 3 vols., edited by Amrit Rai, 3:33-38. Allahabad: Hams, 1962.

Rai, Alok. "A Kind of Crisis: Godan and the Last Writings of Munshi Premchand." Journal of the School of Languages 2, no. 1 (1974): 1-13.

Rai, Gopal. Hindi Kahān̄̄ Kä Itihās (The History of the Hindi Short Story). New Delhi: Rajkamal, 2011.

Rakesh, Mohan. "Bakalam Khud: Udās-Dhaṛkaneṃ Aura Kālatīt Kṣaṇ . . Ek Viśeṣ Manaḥsthiti” (“A Pen and I: Throbs of Sadness and a Timeless Moment ... A Special State of Mind”). Nā̄ Kahāniyām 1, no. 5 (1960): 75-78.

Rakesh, Mohan. "Mis Pāl” ("Miss Pal”). In Mohan Rākeś Kī Sampūrn Kahāniyan (The Complete Stories of Mohan Rakesh), 9-27. New Delhi: Rajpal, 2004.

Rakesh, Mohan. Mohan Rākeś Kī Dāyar̄̄ (Mohan Rakesh's Diary). New Delhi: Rajpal, 1994.

Rakesh, Mohan. Sāmskṛtik Aur Sāhityak Dṛiști (Cultural and Literary Perspectives). New Delhi: Radhakrishnan, 1975.

Roadarmel, Gordon Charles. "The Theme of Alienation in the Modern Hindi Short Story." PhD diss., University of California, Berkeley, 1969.

Rosenstein, Lucy. Introduction to New Poetry in Hindi: Nayi Kavita: An Anthology, edited by Lucy Rosenstein, 1-18. London: Anthem, 2004.

Sangari, Kumkum. "The Politics of the Possible." Cultural Critique 7 (1987): 157-86.

Singh, Dinanath. Hindī Kahān̄ Ke Sau Vars (One Hundred Years of the Hindi Short Story). Meerut: Meenakshi, 2009.

Singh, Namvar. Kahānī: Naȳ̄ Kahān̄̄ (Story: New Story). New Delhi: Lokbharati, 1998.

Singh, Namvar. Kavitā Ke Naye Pratimān (New Models of Poetry). New Delhi: Rajkamal, 1968.

Svobodová. “The Protagonist in Early Nayi Kahani: Mohan Rakesh's ‘Ūrmil Jivan.'” In Heroes and Heritage: The Protagonist in Indian Literature and Film, edited by Theo Damsteegt, 112-126. Leiden: Leiden University Press, 2003.

Tharu, Susie. "Citizenship and Its Discontents." In A Question of Silence: The Sexual Economies of Modern India, edited by Mary John and Janaki Nair, 216-42. London: Zed Books, 2000. 
Todorov, Tzvetan. Genres in Discourse, translated by Catherine Porter. 1978; repr., Cambridge: Cambridge University Press, 1990.

Tyagi, Rajeshwari. "Naȳ̄ Kahānī Ke Trikoṇ Par Ek Ṭeḍī Nazar" ("A Sideways Glance at the Nayi Kahani Triumvirate”). Dharmayuga 15, no. 9 (1964): 39.

Verma, Nirmal. Hara Bāriś Mẹn (During Each Rain). New Delhi: Radhakrishna, 1970.

Verma, Nirmal. "Nayī Kahānī: Lekhak Ke Bahī Khāte Se" ("The New Story: From a Writer's Ledger”). Dharmayuga 15, no. 3 (1964): 18-19.

Warwick Research Collective. Combined and Uneven Development: Towards a New Theory of World Literature. Liverpool: Liverpool University Press, 2015.

Wellek, René, and Austin Warren. Theory of Literature. San Diego: Harcourt, Brace, 1942.

Yadav, Rajendra. "Ek Duniyā Samānāntar” (“A Parallel World”). Ek Duniyā Samānāntar (A Parallel World), edited by Rajendra Yadav. Delhi: Akshar, 1966.

Yadav, Rajendra. "Kahānī: Naī Kahānī Tak" ("From the Story to the New Story"). Kathā Yātrā (The Journey of the Story), edited by Rajendra Yadav, 1-28. Delhi: Akshar, 1965.

Yadav, Rajendra. Kahānī: Svarūp Aura Samvedanā (The Short Story: Form and Sensibility). Dehdradun: National Publishing House, 1968.

Yadav, Rajendra. Muḍ-Mudke Dekhtā Hum: Lagabhaga Ātmakathya (I Look Back Continually: An Approximate Autobiography). New Delhi: Rajkamal, 2001.

Yadav, Rajendra. Premacanda Kī Virāsata Aura Anya Nibandha (Premchand's Inheritance and Other Essays). Delhi: Akshar, 1978.

Yadav, Rajendra. "Śarat Aura Premacanda" ("Sharat and Premchand”). In Devatāom Kī Mūrtiyam (Statues of the Gods), 10-19. Bikaner: Alok, 1952.

Yadav, Rajendra. "Sunie Rajendra Yādav Kā 93 Minaṭ Ințarvyū" ("Listen to a 93 Minute Interview with Rajendra Yadav”). Interview by Anand Prakash. Baițak Vicārom k̄ (Forum of Ideas), 2010. baithak .hindyugm.com/2010/03/listen-rajendra-yadav-long-interview.html.

Yadav, Rajendra. "Yathārthvādī Kahānī-Lekhak" ("The Realist Short Story Writer"). In Khel-Khilaune (Games and Toys), 53-63. New Delhi: Bharatiya Jnanpith Prakashan, 1964. 